This item was submitted to Loughborough's Research Repository by the author.

Items in Figshare are protected by copyright, with all rights reserved, unless otherwise indicated.

\title{
The response of Cladocerans to recent environmental forcing in an Alpine Lake on the SE Tibetan Plateau
}

\section{PLEASE CITE THE PUBLISHED VERSION}

http://dx.doi.org/10.1007/s10750-016-2868-6

\section{PUBLISHER}

(C) Springer

\section{VERSION}

AM (Accepted Manuscript)

\section{PUBLISHER STATEMENT}

This work is made available according to the conditions of the Creative Commons Attribution-NonCommercialNoDerivatives 4.0 International (CC BY-NC-ND 4.0) licence. Full details of this licence are available at: https://creativecommons.org/licenses/by-nc-nd/4.0/

\section{LICENCE}

CC BY-NC-ND 4.0

\section{REPOSITORY RECORD}

Kong, Lingyang, Xiangdong Yang, Giri Kattel, Nicholas John Anderson, and Zhujun Hu. 2019. "The Response of Cladocerans to Recent Environmental Forcing in an Alpine Lake on the SE Tibetan Plateau". figshare. https://hdl.handle.net/2134/24703. 


\section{The Response of Cladocerans in an Alpine Lake on the SE Tibetan Plateau to Recent Environmental Forcing}

Lingyang Kong ${ }^{1,2}$, Xiangdong Yang ${ }^{1, *}$, Giri Kattel ${ }^{1,3,4}$, N. John Anderson ${ }^{5}$ \& Zhujun $\mathrm{Hu}^{6}$

${ }^{1}$ State Key Laboratory of Lake Science and Environment, Nanjing Institute of Geography and Limnology, Chinese Academy of Sciences, Nanjing 210008, China

${ }^{2}$ University of Chinese Academy of Sciences, Beijing 100049, China

${ }^{3}$ Water Research Network, Federation University of Australia, Mt. Helen Campus, Victoria 3350, Australia

${ }^{4}$ Hydrology and Water Resources Unit, School of Infrastructure Engineering, University of Melbourne, Australia

${ }^{5}$ Department of Geography, Loughborough University, Loughborough LE11 3TU, UK

${ }^{6}$ School of Geography Science, Nanjing Normal University, Nanjing 210008, China

*Corresponding author. Tel.: +86(0)25 86882149

E-mail address: xdyang@niglas.ac.cn 


\begin{abstract}
Global environmental change has affected aquatic ecosystems of the southeast Tibetan Plateau during the past 200 years, altering the composition and biomass of primary producers (e.g. algae). However, the response of primary consumers (e.g. cladocerans) to this recent environmental forcing is not well documented. Cladoceran remains from a small, remote alpine lake (Moon Lake) in Sichuan Province (SW China). Samples from sediment traps (1-yr deployment), surface sediments covering a range of water depths and a short 22.5-cm sediment core were analysed. Littoral forms, notably Chydorus sphaericus and Acroperus harpae, together with Daphnia pulex dominated the cladoceran community. Remains of these cladocerans were well represented in the sediment core assemblages as indicated by their relative abundance in the surface sample. There was a marked increase in the abundance of $D$. pulex and total cladoceran fluxes in the sediment core from ca. $1880 \mathrm{AD}$, coinciding with the changes in diatom assemblages and pigments. Analysis of the multi-proxy data (cladocerans, diatom, pigment, total organic carbon, $\mathrm{C} / \mathrm{N}$ ratio, air temperature and atmospheric $\mathrm{NO}_{3}$ records) suggest that both direct and indirect climatic forcing, coupled with enhanced nutrient supply (e.g. $\mathrm{NO}_{3}$ deposition) effects on primary producers have changed cladoceran community dynamics in Moon Lake over the last 200 years.
\end{abstract}

Keywords: Cladoceran zooplankton; nutrient loading; climatic forcing; alpine lake; trophic dynamics; southwest China. 


\section{Introduction}

Evidence from palaeolimnological studies suggests that pronounced and unprecedented limnological and ecological changes have occurred over the past few centuries in many high altitude lakes (Battarbee et al., 2002; Catalan et al., 2013). Unlike lowland lakes, where the cultural impact of humans is unambiguous, remote alpine lakes are affected largely by climatic forcing such as temperature increases, variability in precipitation and snow cover (Battarbee et al., 2009) and more subtle effects of atmospheric pollution. The sedimentary profiles of biological remains collected from alpine lakes has been inferred to reflect the climatic forcing over the recent past (Lotter et al., 1997). In particular, over the last two centuries, ecosystems of many high mountain lakes across the world have shown different responses, such as loss of biodiversity and shift in biological assemblages, due to rapid changes in their physical environment (Catalan et al., 2002; Thienpont et al., 2015). Rise in temperature has also influenced the nutrient dynamics in alpine lakes; for example, regional warming in North America has enhanced nutrient release from the catchment influencing the lacustrine productivity (Saros et al., 2010). A global increase in atmospheric nutrient deposition is also affecting high alpine lake ecosystems (Neff et al., 2008; Wolfe et al., 2001). For example, an increased atmospheric nutrient loading has enhanced autochthonous production as well as the altered phytoplankton community structure and dynamics in North American alpine lakes (Elser et al., 2009; Saros et al., 2010; Holtgrieve et al., 2011). The changes in primary productivity in alpine lakes can have considerable implications for the dynamics of primary consumers such as cladoceran zooplankton (Frey, 1988).

Cladoceran zooplankton play a central role in the food web structure and ecosystem dynamics of lakes (Eggermont \& Martens, 2011; Alric et al., 2013). They are significant grazers of the lower trophic levels (e.g. algae) as well of detritus and bacteria and are also an 
important prey item for secondary consumers such as planktivorous fish (Jeppesen et al., 2001). In high alpine lakes, cladocerans are sensitive to environmental forcing for various reasons. A small change in water temperature in these lakes can have a larger effect on the habitat and the reproductive capacity of cladocerans (Frey, 1988). Many alpine lakes are also fishless, and can have predominantly pelagic primary producers and consumers with the result that pelagic community dynamics are sensitive to external forcing. In these conditions, cladocerans become important as indicator species and for understanding the long-term ecological change of these lakes (Frey, 1986; Alric et al., 2013). Furthermore, the generally good preservation of their remains in lake sediment after death, the associated record of diversity of subfossil cladoceran assemblages, has allowed the reconstruction of long-term environmental forcing in high altitude lakes around the world (Lotter et al., 1997, 1998; Kamenik et al., 2007; Kattel et al., 2008; Alric \& Perga, 2011).

Among cladocerans, the planktonic genus, Daphnia spp. Is often considered as keystone species, and plays a pivotal role in structuring the pelagic community in many temperate and alpine lakes (Persson et al., 2007). In fishless alpine lakes, the effect of environmental forcing, such as climate change and/or enhanced nutrient loading, can affect the patterns of composition and biomass of Daphnia sp. to a greater extent than in lowland lakes (Nevalainen et al., 2013). Studies in European high altitude lakes (Catalan et al., 2009) and the Himalayas (Manca \& Comoli, 2004) showed that the dynamics of Bosminid and Daphnid communities were largely regulated by the duration of the ice-cover periods of the open water zone. Several other studies also suggest that during the summer ice-free period, the littoral margin of the high altitude lakes supports growth of submerged aquatic plants. Increased vegetation cover during summer can favour growth and colonization by littoral cladocerans (e.g. Chydorid) (Hofmann, 1987; Jeppesen, 1997). 
The southeast margin of the Tibetan Plateau in south-western China contains a large number of the world's high altitude lakes, which were mostly formed by glacier activity. These lakes are often ultra-oligotrophic with simple food web and ecology. Due to the absence of high order consumers, these lakes have relatively low species richness and diversity, a condition similar to the European alpine lakes (Battarbee et al., 2009). Recent studies on diatom- and algal pigment- inferred past environmental change suggested that there has been an increasing tendency of climatic warming and widespread nutrient loading on lakes across the region over the past two centuries (e.g. Wang et al., 2011; Hu et al., 2014). However, there are no studies carried out yet in the region that focus on the response of primary consumers (e.g. cladoceran) to recent environmental forcing.

Previously, a multi-proxy study of diatoms, pigments, $\mathrm{C} / \mathrm{N}$ and stable isotopes $\left(\delta^{13} \mathrm{C}\right.$ $\delta^{15} \mathrm{~N}$ ) by Hu et al. (2014) at Moon Lake, suggested the changes in primary producers (diatoms, algal pigments) was due to enhanced atmospheric deposition of reactive nitrogen (Nr) coupled with recent warming in southwest China. The diatoms also changed significantly during the Little Ice Age (LIA) with a clear response to post-LIA regional climate warming (Hu et al., 2014). The aim of this present study was therefore to extend our understanding of the effect of recent environmental forcing (temperature, $\mathrm{Nr}$ deposition) on structure and dynamics of the cladoceran community over the past two centuries inferred from changes in the sub-fossil assemblages and their diversity in a high alpine lake (Moon Lake), located on the southeast margin of the Tibetan Plateau (Sichuan Province, China). 


\section{Materials and Methods}

Study site

This study was conducted at Moon Lake located in Xiaojin County, Sichuan, Southwest

China $\left(31^{\circ} 29^{\prime} 15.11^{\prime \prime} \quad \mathrm{N}, 102^{\circ} 20^{\prime} \quad 13.45^{\prime \prime} \quad\right.$ E) (Fig. 1a). The study lake is relatively small ( 7 ha), oligotrophic (total nitrogen $=0.25 \mathrm{mg} / \mathrm{l}$, total phosphorus $<0.001 \mathrm{mg} / \mathrm{l}$ ), fishless, clear water (Secchi depth: $14 \mathrm{~m}$ ) and alkaline ( $\mathrm{pH}=8.2)$; the lake is located above the present tree-line at an altitude of $4260 \mathrm{~m}$ a.s.l. and has a maximum water depth of $21 \mathrm{~m}(\mathrm{Hu}$ et al., 2014). The catchment area is about 130 ha, with the presence of large areas of bare rocks and limited cover of open tundra vegetation on the lower parts of the catchment. During the growing season, aquatic plants, mainly Potamogeton pectinatus, occur sporadically in the southwest area of the lake. There is no direct human activity in the catchment. The lake basin has a steep-sided morphometry with a single outflow at the northwest shore (Fig. 1b), but has no discernible inlets.

Annual air temperature and surface water temperature have been monitored using Hobo Dataloggers (TidbiT v2) over a one-year (2013-2014) period. The mean annual air temperature is $1.0^{\circ} \mathrm{C}$, and the mean maximum (July) and minimum (January) air temperatures are $8.9^{\circ} \mathrm{C}$ and $-6.0^{\circ} \mathrm{C}$, respectively. From June to October, the lake is ice-free and the water temperature shows a similar trend to that of the air temperature (Fig. 2a). From November to late April, the lake is ice-covered and inversely stratified. During winter the lake and its catchment are covered mostly by snow and the snow melt is released into the lake during summer. However, during summer, the hydrological budget of the lakes is affected by strong monsoon rainfall. The rainfall records (1952-2005) from the nearest Meteorological Station in Xiaojin County (2369 m a.s.l.) showed that the mean annual precipitation of the 
region is approximately $620 \mathrm{~mm}$, about $77 \%$ of whichoccurs during the summer monsoon season (May to September).

Sample collection

Sampling of cladoceran remains was carried by deployment of sediment traps, analysis of surface sediment samples together with a short-sediment core. For understanding the composition and spatial distribution patterns of cladoceran remains in surficial sediments of the lake, 16 surface-sediment $(1 \mathrm{~cm})$ samples (Fig. 1b) located at different water depths across the basin were collected by using a Kajak gravity corer (Fig.1b).

For the analysis of the remains of cladocerans in lake sediments over the recent past, a 22.5-cm long sediment core was taken from the deepest point of the lake (20.5 m) in 2012 (Fig. 1b) using a Kajak gravity corer. The sediment core was sub-sectioned at every $0.5 \mathrm{~cm}$ resolution intervals in the field, and stored at $<4{ }^{\circ} \mathrm{C}$ immediately after the collection.

In order to investigate the composition (abundance and biomass production) of pelagic cladocerans in the lake today, two sediment traps (Fig. 1b) each made of four parallel 60-cm long polyvinyl chloride (PVC) tubes (total active area: $58 \mathrm{~cm}^{2}$ ) were deployed in the central part of ( 20 m water depth) of the lake on 15 August 2013 till 31 July 2014 (approximately 1 year). The upper edges of each trap were placed approximately $5 \mathrm{~m}$ and $15 \mathrm{~m}$ below the surface of the water respectively. Due to the long period of ice-cover (Fig. 2a), the sediment traps were only emptied twice within the 1 year period: on 1 November 2013 and 31 July 2014 respectively. In this study, the sampling period from 1 November 2013 to the end of July 2014 is considered to represent the early growing season, while the period from 15 August to the end of October 2013 represents the late growing season at the study site. 
Sample preparation

The analysis of the cladocerans remains from both the surface sediments and the sediment core samples followed standard methods (Szeroczyńska \& Sarmaja-Korjonen 2007). A known quantity (2-20 g) of wet sediment was deflocculated in $10 \% \mathrm{KOH}$ at $60{ }^{\circ} \mathrm{C}$ for 45 minutes. After washing through a $38-\mu \mathrm{m}$ sieve, the retained material was counted on microscopic slides and analyzed under the microscope at 200× magnification. All cladoceran remains (head-shields, carapaces, post-abdomen and post-abdominal claws) were tabulated separately, but only the most frequently encountered body parts for each taxon were used for estimating taxon abundance. For the Daphnia sp., only post-abdominal claws and ephippia were used, as they were the only parts preserved. At least 200 cladoceran individuals were counted for each sample. Taxonomic identification of cladocerans was based on Szeroczyńska \& Sarmaja-Korjonen (2007) and Chiang \& Du (1979).

Cladoceran abundances, both as percentages of the total remains counted and concentrations as number of individuals per gram dry weight (inds $\mathrm{g} \mathrm{dw}^{-1}$ ) were calculated (Amsinck et al., 2003). Considering changes in bulk sediment accumulation rate, cladoceran accumulation rate (inds $\mathrm{cm}^{-2} \mathrm{y}^{-1}$ ) was used to express changes in cladoceran biomass. The planktonic to littoral (P:L) ratios were also calculated based on the abundance of total planktonic and littoral cladocerans. The P:L ratio is an indicator of shifts in cladoceran habitats as a result of changes in lake levels over time (Frey, 1986) and the changing contribution of littoral production.

For the analysis of the cladocerans remains in the sediment trap, all remains collected from a tube on the trap were initially freeze-dried. The net dry weight of total catch was calculated and then the material was subjected to $10 \% \mathrm{KOH}$ treatment and all preserved cladoceran body parts were counted and identified as described above. The results are expressed as percentage abundance; and the mean daily flux rate (inds $\mathrm{cm}^{-2}$ day $^{-1}$ ) and the 
mean yearly flux rate (inds $\mathrm{cm}^{-2} \mathrm{yr}^{-1}$ ) calculated as the total catch of cladocerans in the sediment trap divided by the number of days or months of exposure.

Palaeoecological and chemical proxies, regional temperature trends and atmospheric $\mathrm{Nr}$

Other biological proxies were used to compare with cladoceran records derived in this study., such as the pigment PCA first axis sample scores (Pi-PCA1), diatom PCA axis 2 (Di-PCA2) organic carbon (TOC), $\mathrm{C} / \mathrm{N}$ ratio, and carbon stable isotope $\left(\delta^{13} \mathrm{C}\right)$ values of bulk sediments from the 2011-dated (master) core (Hu et al., 2014). See Hu et al. (2014) for methods and a full discussion of the interpretation of these proxies (Hu et al. 2014).

The long-term mean annual temperature ( $\left.\mathrm{T}_{\text {annual }}\right)$ used as evidence of regional climate change record in this study, was reconstructed using the ECHO-G model (Kuang et al., 2008) and based on the instrumental data starting from 1960 from the nearby meteorological station in Xiaojin County. The reconstructed $\mathrm{T}_{\text {annual }}$ (Min, unpublished data) are significantly correlated with Xiaojin annual temperatures from 1960 to 2007 ( $r=0.94, p<0.001, n=48)$ and therefore extend the time series of regional temperature back to ca. $1800 \mathrm{AD}$ (Fig. 2b). In this study, the $\mathrm{NO}_{3}{ }^{-}$concentration from a Himalayan ice core (Thompson et al., 2000) was used as a proxy for the regional atmospheric $\mathrm{Nr}$ deposition in southwest China. These proxies were compared with the subfossil remains of cladocerans in the sediment core.

\section{Core chronology}

Two parallel cores were taken in 2011 by Hu et al. (2014). The first core was used for diatom and pigment analysis, while the second core was used for ${ }^{210} \mathrm{~Pb}$ and ${ }^{137} \mathrm{Cs}$ dating (see Hu et al. [2014] for details). The age-depth model was then established based on the constant rate of sedimentation (CRS) as described by Appleby (2001). In 2012, a third core for cladoceran analysis was collected from a similar location to that used in the previous study. In order to 
obtain the age-depth model for the third core (cladoceran core), core correlation undertaken based on the visual correlation of the loss on ignition (LOI) profiles of the ${ }^{210} \mathrm{~Pb}$ dated core used by Hu et al (2014) and the core used in this study.

Statistical analyses

Detrended Correspondence Analysis (DCA) was used to explore the temporal changes in the cladoceran stratigraphy. An exploratory DCA, with cladoceran percentage data, showed that the gradient length was short (1.24 standard deviation), so Principal Components Analysis (PCA) was used to summarize the major changes in the cladoceran assemblage. Cladoceran percentage data were squared-root transformed prior to PCA. All analyses were performed in CANOCO Program, Version 4.5 (ter Braak \& Šmilauer, 2002). The zonation of the cladoceran stratigraphy was determined according to the cluster analysis using constrained incremental sum of squares (CONISS) within Tilia Graph Program (Grimm et al., 2011).

\section{Results}

Cladoceran remains from the sediment trap catches and spatial array of surface sediments

Chydorus sphaericus O. F. Müller and Acroperus harpae Baird were the most dominant species recovered from the surface sediment samples with an average abundance of $47 \%$ and 28\%, respectively. Pleuroxus sp. was present sporadically in offshore samples and has maximal abundance at the east edge of the lake ( $\sim \mathrm{m}$ water depth). Other littoral taxa such as Alona guttata Sars, Alona rustica Scott, A. quadrangularis O. F. Müller, A. rectangula Sars and $A$. costata Sars were common in most surface sediment samples but all had relatively lower abundances. The planktonic species Daphnia pulex Leydig was most abundant in the deeper parts of the basin (>16 m) (Fig. 3),. With the exception of Daphnia, Cladoceran remains in samples located in the deep- water area ( $>16 \mathrm{~m})$ show a similar composition to 
samples taken from across the basin; for example, the average abundance of $C$. sphaericus and $A$. harpae in the open-water area are high as $\sim 55 \%$ and $\sim 17 \%$, respectively, and other littoral species also had an similar abundance (18.4\%) to their average (21\%) in all samples. With regard to the concentration of cladoceran remains in surface samples, the remains of $D$. pulex were positively correlated $(\mathrm{r}=0.75$, $\mathrm{p}<0.001)$ with water depth (Fig. 3),, while the distribution of the remains of the most common littoral taxa did not show significant change along the water-depth gradients (Fig. 3),. Although C. sphaericus and A. harpae were mainly found in shallower areas $(<8 \mathrm{~m})$ at the northwest and southwest edges of the lake (Fig. 3), there are noticeable occurrence of C. sphaericus (281 inds $\mathrm{g} \mathrm{dw}^{-1}$ ) and A. harpae (75 inds g $\left.\mathrm{dw}^{-1}\right)$ in samples located in the open-water area $(>16 \mathrm{~m})$. Using the ${ }^{210} \mathrm{~Pb}$ sedimentation rate at the Moon Lake, $1 \mathrm{~cm}$ of surface sediment taken from the open-water area (>16 m) represents about 4.5 years, which means that the flux of $D$. pulex and $C$. sphaericus remains would be approximately 0.76 inds $\mathrm{cm}^{-2} \mathrm{y}^{-1}$ and 2.39 inds $\mathrm{cm}^{-2} \mathrm{y}^{-1}$ respectively.

. A total of 12 cladoceran taxa representing seven genera were identified in the surface sediment samples (Fig. 4). C. sphaericus was the dominant species with relatively high proportion (32-91\%) during the sampling period. Littoral species such as A. harpae, A. rustica and $A$. costata had relatively low percentages $(<10 \%)$. It is notable that the deposition flux of all cladoceran remains increased markedly from the early growing season to the late growing season (Fig. 4). For example, both the abundance and accumulation flux of planktonic species $D$. pulex remains showed a sharp increase from almost no individuals in the early growing season to $\sim 39 \%\left(0.16\right.$ inds $\mathrm{cm}^{-2}$ day $\left.^{-1}\right)$ of flux in the late growing season.

Comparing the average percentage abundance of taxa in the sediment trap samples with that in the surface sediment samples , abundance of $C$. sphaericus was higher in the traps (65\%) than in sediment (47\%), while for A. harpae the reverse was observed: traps (5\%) and surface sediments (28\%). In the case of the records of $D$. pulex, their average abundance in 
traps is higher (21\%) than that in the surface sediment samples (4\%). However, there were differences in fluxes of planktonic and littoral cladocerans between traps and core-top sample. Unlike A. harpae remains, which had approximatelysimilar fluxes in both traps (2.2 inds $\mathrm{cm}^{-2} \mathrm{y}^{-1}$ ) and core-top sample (2.4 inds $\left.\mathrm{cm}^{-2} \mathrm{y}^{-1}\right)$, the flux of C. sphaericus and D. pulex were higher in the trap (30.4 inds $\mathrm{cm}^{-2} \mathrm{y}^{-1}, 10.5$ inds $\mathrm{cm}^{-2} \mathrm{y}^{-1}$ ) than in the core-top sample (2.3 inds $\mathrm{cm}^{-2} \mathrm{y}^{-1}$ and 4.2 inds $\mathrm{cm}^{-2} \mathrm{y}^{-1}$ ) respectively. Assuming that the remains of cladocerans caught in the sediment trap are representative of the source communities, and are also preserved in the deep lake sediment, the trap assemblages were then compared with the surface sample of the sediment core used for the historical trends. With the exception of $A$. harpae, which was over represented by $\sim 8 \%$, the remains of all other cladoceran species including the dominant species in the traps, C. sphaericus and D. pulex, had a similar loss rate (average $\sim 76 \%$ ) (Fig. SM1).

Remains of sub-fossil cladoceran assemblages in the sediment stratigraphy

A total of 19 species of subfossil cladoceran remains were identified in the sediment core (Fig. 5) and the core assemblages were divided into three distinct zones using CONISS.

Zone I: c. 1813- c. 1880 AD. The remains of two littoral cladocerans, C. sphaericus and A. harpae dominated this zone, while the abundance of other littoral species, such as A. rustica and $A$. rectangula, were low. The remains of planktonic $D$. pulex together with the P:L ratio, Cl-PCA1 and total cladoceran flux were very low in this zone (Fig. 5).

Zone II: c. 1880- c. 1906 AD. Of the littoral species, the remains of C. sphaericus began to decline, while the remains of $A$. harpae were more constant but most other littoral taxa declined. The remains of $D$. pulex began to increase in the1880s. Remains of Bosmina (B. coregoni Baird, B. longispina Leydig and B. longirostris O. F. Mülle) were also recorded in 
this zone. Relative to Zone I, both Cl-PCA1 and the P:L ratio of cladocerans increased in this zone with some small fluctuations.

Zone III: c. 1906- c. 2012 AD. The remains of the dominant littoral cladocerans were constant in this zone. However, the remains of D. pulex increased markedly, and the remains of Bosmina disappeared. The P:L ratio showed some variation between 1906 and 1960, then decreased (Fig. 5). The total sediment cladoceran flux began to increase from the 1920s, and reached a maximum during the period 1950-1970s. During the 1980s both the P:L ratio and the Cl-PCA1 increased.

Comparison between subfossil remains of cladocerans in sediment core and subfossil diatom, pigment and geochemistry records

The subfossil remains of cladocerans from this study were compared with subfossil records of diatom and pigments taken from Hu et al. (2014). The changes in assemblage of cladocerans, diatoms and pigments all showed similar trends in the past (Fig. 6). The total planktonic cladoceran and planktonic diatom assemblages corresponded with the Pi-PCA1, where the changes were pronounced after the 1940s (Fig. 6). Around 1960-1980s, planktonic cladoceran percentage abundance, Cl-PCA1 and cladoceran flux all declined, while Di-PCA2 increased (Fig. 6).

The total organic carbon (TOC) content was low prior 1880s, as were the percentage abundance and flux of planktonic cladocera during this period, after which all increased. The $\mathrm{C} / \mathrm{N}$ and $\delta^{13} \mathrm{C}$ values were relatively high prior to $\sim 1880$ but then decreased. The $\delta^{13} \mathrm{C}$ was correlated with the $\mathrm{C} / \mathrm{N}$ ratio $(\mathrm{r}=0.91, p<0.001)$, as both of these variables began to decline after the 1880s, when cladoceran abundance began to increase (Fig. 6).

The reconstructed annual temperature shows a distinct cooling between ca. 1800 and 1850 which is referred to as the little ice age (LIA) (Fig. 2b), after which annual temperature 
shows an irregular increasing trend with obvious fluctuation (Fig. 2). The $\mathrm{NO}_{3}{ }^{-}$concentration in an ice core from the Himalayas began to increase at this time (Thompson et al., 2000) and the trend is consistent with the changes in both biological (cladoceran, 0.38, $\mathrm{P}<0.05$; pigment, $\mathrm{r}=0.71, \mathrm{P}<0.01$; diatom PCA2 ****) and geochemical proxies $(\mathrm{TOC}, \mathrm{r}=0.64, \mathrm{P}$ < 0.001) from the Moon Lake sediment core (Fig. 6).

\section{Discussion}

The contemporary Moon Lake cladoceran community as reflected by sediment trap catches and remains in surface sediments

The occurrence of cladoceran remains in both the sediment traps and surface samples at Moon Lake suggests that the zooplankton ecology of this lake is relatively simple with low species diversity as has been observed at sub-tropical alpine lakes (Manca \& Comoli, 2004). The community structure in Moon Lake is dominated mainly by littoral forms (C. sphaericus and A. harpae) and a few planktonic (e.g. D. pulex) cladocerans, the occurrences of most other littoral (Alona spp.) and planktonic (Bosmina spp.) species are sporadic (Fig. 4). Most alpine lakes are oligotrophic in nature with limited growth of submerged vegetation with the results that the diversity of littoral-vegetation-preferring cladocerans is low (Hofmann, 1987). However, the $C$. sphaericus and A. harpae occur commonly in alpine lakes (Hofmann, 1987; Lotter et al., 1998), and Moon Lake is no exception, where even the limited growth of submerged vegetation during the ice-free season supported their development (e.g. Whiteside et al., 1978). Although C. sphaericus is usually considered as littoral species, it can utilize pelagic resources particularly when lake productivity increase (Hofmann, 1987; Frey, 1988) or when other taxa decline (Manca \& Comoli, 1995; Korhola, 1999). Thus it is not surprising that so C. sphaericus remains were recovered from the sediment traps and occurred in a number of the surface sediment samples (Fig. 3). Daphnia pulex was common in Moon Lake 
in both the trap catches and the deeper sediment core samples; it has been reported previously from alpine environments where it can be quite successful (Weider, 1987; Korhola \& Rautio, 2001). This is because Daphnia has a competitive advantage over the other cladoceran species that occur in alpine lakes by feeding effectively on a wide range of food types including non-siliceous algae and diatoms during ice-free period (Demott, 1982; Kankaala, 1988; George \& Hewitt, 2006).

Representation of the whole lake cladoceran community in sediment core assemblages Sediment traps and surface samples provide information regarding the temporal and spatial variation in biota preserved in deep lake sediments (Jeppesen et al., 2003). The integration and homogenization of the remains of both littoral and open-water cladocerans occurs prior to deposition in deep lake sediments and is the result of lake mixing and resuspension processes (Kattel et al., 2007). The contemporary cladoceran community at Moon Lake is reasonably well reflected in the sediment core, at least qualitatively, as shown by the mixture of the dominant cladoceran species in both the trap and surface sediment assemblages. All 12 cladoceran species occurring in the trap catches, including the remains of the dominant forms (D. pulex and C. sphaericus) are recorded in surface sediments from the deepest part of the lake (Fig. 3, Fig. 4). Similarly, the remains of the littoral cladocerans (C. sphaericus and $A$. harpae) that are dominant in the surface sediment samples are also represented in the sediment core assemblages (Fig. 5). However, quantitatively, there are bigger differences between the littoral and pelagic forms due to their differential distribution across the basin, as has been shown for diatoms (Anderson, 1990). The variation in the fluxes of planktonic and littoral cladoceran remains between both the deep and shallow trap catches (Fig. 4) and core-top sample (see Fig. SM1), indicates some differential preservation and distribution of the remains in the sediment core assemblages and may bias community representation. The 
higher concentration of littoral cladocerans including $A$. harpae and $C$. sphaericus in surface sediment samples collected from the lake margin were anticipated as the death and deposition of these cladocerans occurs primarily close to their source habitats (Whiteside et al., 1978).

After death, various factors such as the source habitats, basin morphometry, lake water depth and transport-sedimentation processes (energy inputs) as well as the sinking velocity can influence the taphonomy of the remains, and, as a result, the composition of the fossil cladoceran assemblages in deep sediment core can be quantitatively and qualitatively unrepresentative (Frey, 1988; Larsen \& MacDonald, 1993; Blais \& Kalff, 1995; Lotter et al. 1997; Kattel et al. 2007; Alric \& Perga, 2011). This needs to be taken into account when interpreting the observed changes in the cladoceran assemblages in terms of environmental change and the associated drivers.

Recent environmental forcing and the long-term change of subfossil cladoceran assemblages The changes in subfossil assemblages of cladocerans in Moon Lake sediments over the past 200 years suggest that both natural (i.e. recovery from the LIA) and anthropogenic global change processes (recent warming and $\mathrm{Nr}$ deposition) may have played a significant role. During the Little Ice Age (1800-1860 AD) conditions for the ecosystem at this alpine lake was cold and hostile. Cladoceran species diversity during this time was relatively low (N2 index $=7.3$ ) compared to that after LIA (see below). The low abundance of planktonic cladocerans (mainly Daphnia sp.), but also the increased abundances of littoral species such as $A$. harpae and $C$. sphaericus during the LIA suggests that the lake was less productive due to low temperatures and poor nutrient supply. The low air temperatures, reduced TOC values, low diatom and pigment abundance (see Hu et al. 2014) also suggest a period of cold climate during the LIA (Fig. 6). The dominant cladocerans recorded at Moon Lake during this time, A. harpae and C. sphaericus, are both regarded as cold tolerant species (Hofmann, 1987). 
The occurrence of these forms suggests that these littoral macrophyte-associated species were more competitive during the shorter growing seasons of summers in the LIA (Whiteside et al., 1978; Thienpont et al., 2015).

Species diversity (N2 index $=9.4)$, P:L ratio and abundance of Daphnia and Bosmina together with changes in diatom assemblages (Di-PCA2) and pigments (Pi-PCA1), C/N ratio and the decreased $\delta^{13} \mathrm{C}$ values after the LIA (1880-1915) (Fig. 6) indicate the amelioration of the environment at Moon Lake (a longer growing season due to the longer ice-free period) due to the natural climate recovery. However, the remains of the cold-preferring cladocerans such as, A. harpae and C. sphaericus (Hofmann, 1987) continued to increase which may be related to increased input of snow-melt, which would reducing the surface water temperature of the lake combined with increased growth of littoral vegetation as the growing season lengthened (Whiteside et al., 1978; Saros et al., 2010; Thienpont et al., 2015).

After 1910 , the abundance of $D$. pulex increased, but surprisingly the populations of Bosmina sp. disappeared from the Moon Lake (Fig. 5). This suggests that gradual rise in temperature following the LIA and the increasing $\mathrm{Nr}$ deposition (as recorded by the ice core $\mathrm{NO}_{3}$ profile) favoured the growth of wide range of algae and diatoms and increased lake production (cf. increasing TOC); a situation where Daphnia out competed Bosmina due to its feeding methods (Demott \& Kerfoot, 1982). After c. 1970 AD, the abundance of planktonic species D. pulex and cladoceran flux declined, which was consistent with reduced abundance of planktonic diatom (Cyclotella species), pigments and TOC content (Fig. 6). These changes may have been related to a short cold spell during the 1960-1970s (Hu et al., 2014). The meteorological data from Xiaojin County show that the mean annual atmospheric temperature decreased in this period. The winter temperature dropped markedly during the 1960s, being $2.5^{\circ} \mathrm{C}$ lower than the period after $1970 \mathrm{AD}$ (Fig. 2b). This cold event was also clearly recorded by the tree-rings in west Sichuan Province (Shao \& Fan, 1999) and the 
meteorological station at the southeast Tibetan Plateau (Liang et al., 2009). The short cold spell could have restricted the growth of algae and cladocerans in spite of the increasing trend of nutrient loading in Moon Lake. However, the success of D. pulex in Moon Lake compared to other pelagic consumers for over the past century indicates the possible effects of climatic forcing.

An important question is how the climatic forcing affected the structure and dynamics of cladocerans in Moon Lake over the past two centuries relative to other global change processes such as Nr deposition? Cladocera in European and North American alpine lakes are reported to have been influenced by both direct and/or indirect environmental forcing (Catalan et al., 2002). The rise in temperature potentially alters surface water temperature, the duration of ice-cover period, and the input of catchment snow-melt water in alpine environments (Rühland et al., 2006), all of which can directly influence cladoceran growth and reproduction, and indirectly on their food resources by mobilizing nutrient supply used by primary producers (Kattel et al., 2008; Saros et al., 2010). However, it is difficult to understand the direct and indirect effects of climatic forcing on Moon Lake due to the limited climatic data available for southwest China.

A tree-ring study in the southwest China suggests that there is a significant positive correlation between mean summer air temperature records and tree-ring data after $1850 \mathrm{AD}$ (Liang et al., 2009). The significant correlation between the reconstructed mean regional air temperature and total cladoceran fluxes $(\mathrm{r}=0.358, \mathrm{p}<0.05)$ and Pi-PCA1 $(\mathrm{r}=-0.448, \mathrm{p}<$ 0.05) suggest a possible direct effect of climate change on the Moon Lake ecosystem. However, firstly, the mean air temperature records were not directly measured and difficult to verify, and secondly, there were periods during 1850-1880 AD, a period with positive temperature trends, which were not comparable with lower fluxes of cladocerans (Fig. 6) suggesting negative regional climatic feedbacks, which may be due input of cold water 
associated with regional climate warming (e.g. Wischnewski et al., 2011). In a previous study, Hu et al. (2014) argued that the increasing atmospheric nitrogen deposition, which is indicated by a gradual decrease in $\delta^{15} \mathrm{~N}$ in the lake sediment and an increased $\mathrm{NO}_{3}{ }^{-}$ concentration in the Himalayan ice core (Thompson et al., 2000) (Fig. 6) may play an important role in driving the primary production at Moon Lake. In oligotrophic lakes such as the present study site, even a small increase in atmospheric $\mathrm{N}$ deposition, especially in the inorganic form, can increase the biological production if these systems were nitrogen limited in their natural state (e.g. Bergström and Jansson 2006).

The rise in air temperatures in alpine lakes also indirectly affects the composition of cladocerans by altering the ice-cover, surface water temperature, nutrient cycling and lake stratification (Koinig et al., 2002; Smol et al., 2005; Kattel et al., 2008; Catalan et al., 2009). In Moon Lake, the longer growing season following the LIA favoured the growth and development of cladocerans due to increased availability of food resources. The snow-melt inputs from the catchments are nutrient- and mineral- rich, supporting the growth of primary producers and hence consumers (Catalan et al., 2002; Gąsiorowski \& Szeroczyńska, 2004). The effects of other aspects of global environmental change on the Moon Lake ecosystem was highlighted by Hu et al. (2014), who reported an increased atmospheric nitrogen deposition based on $\delta^{15} \mathrm{~N}$ values in the sediment core. The increased atmospheric nitrogen deposition in the area is also supported by the evidence of an increased $\mathrm{NO}_{3}{ }^{-}$ concentration in the Himalayan ice core (Thompson et al., 2000) (Fig. 6). Such changes in nutrient dynamics in Moon Lake can have considerable implications for food web structure and ecosystem dynamics. The changes in the diatom and pigment records (Fig. 6) highlight this role of nutrients (either catchment derived [due to climate effects] or from increased atmospheric sources, ie. dust and $\mathrm{Nr}$ ) on primary producers which is then transferred to the cladocerans. Supporting this inference is the correlation between cladoceran PCA1 and the 
$\mathrm{C} / \mathrm{N}$ ratio $(\mathrm{r}=0.79, \mathrm{p}<0.01)$; total cladocera concentrations are also well correlated with both diatom and pigment concentration ( $0.63, \mathrm{p}<0.01$ and $0.67, \mathrm{p}<0.01$ respectively) indicating trophic interactions. For instance, in oligotrophic alpine lakes in north America, the uptake of $\mathrm{NO}_{3}{ }^{-}$by water column algae and diatoms is usually high (Dodson \& Frey, 2001) resulting in the higher growth and abundance of pelagic cladocera, including the more competitive Daphnia sp. (Scholten et al., 2005). The bottom-up transfer of nutrients can also influence the taxonomic and functional structure of primary producers (algae) and first order consumers such as cladocera (Chen et al., 2010). The sustained growth of pelagic Daphnia in Moon Lake after the 1880s is possibly as a result of the increased uptake of $\mathrm{NO}_{3}{ }^{-}$by algae and diatoms (e.g. Dodson \& Frey, 2001; Scholten et al., 2005).

\section{Conclusions}

Climate change appears to have acted both directly and/or indirectly in structuring the community dynamics of cladocerans in Moon Lake over the past 200 years. The cladoceran assemblages were dominated by cold tolerant species and the low flux of all taxa during the LIA suggests a possible direct effect of climate on the cladoceran community at this time. In contrast, the relationship between the changes in the cladoceran fluxes, diatom assemblages, pigments and TOC profiles and other independent proxies (such as $\mathrm{NO}_{3}$ ) during the $20^{\text {th }}$ Century indicates indirect effects of the late $20^{\text {th }}$ century regional climatic forcing in the southwest China coupled with increased nutrient inputs, both from catchment and atmospheric sources. Further investigations on similar lakes in the region provide better understanding of the effect of climate change on ecosystems. 


\section{Acknowledgements}

We are grateful to Yuxin Zhu, Weilan Xia, Shen Min, Dr. Suzanne McGowan and Dr. Qian Wang for providing the chemical, chronological, reconstructed temperature, and pigment data as well as field assistance. GK acknowledges the assistance of the Chinese Academy of Sciences for the CAS-PIFI Visiting Fellowship program at NIGLAS; NJA acknowledges the support of the Chinese Academy of Sciences (Senior Visiting Professorship) and the Royal Society. This study was supported by the National Basic Research Program of China (Grant No. 2012CB956100), the National Science Foundation of China (Grant No. 41272379, 41502170), Nanjing Institute of Geography \& Limnology, CAS (Grant No.

NIGLAS2012135004) and the Jiangsu Collaborative Innovation Center for Climate Change. Finally, we would like to thank editors of Hydrobiologia, two anonymous reviewers, and B Alrcic (France), for their constructive reviews.

\section{Compliance with Ethical Standards}

The authors declared that they have no conflict of interest. This research does not involve human participants and/or animals. All the co-authors agree with the submission of this paper to Hydrobiologia. 


\section{References}

Alric, B., \& M. E. Perga, 2011. Effects of production, sedimentation and taphonomic processes on the composition and size structure of sedimenting cladoceran remains in a deep subalpine lake: paleo-ecological implications. Hydrobiologia 676: 101-116.

Alric, B., J. P. Jenny, V. Berthon, F. Arnaud, C. Pignol, J. L Reyss. P. Sabatier \& M. E. Perga, 2013. Local forcings affect lake zooplankton vulnerability and response to climate warming. Ecology 94: 2767-2780.

Amsinck, S. L., E. Jeppesen \& D. Ryves, 2003. Cladoceran stratigraphy in two shallow brackish lakes with special reference to changes in salinity, macrophyte abundance and fish predation. Journal of Paleolimnology 29: 495-507.

Appleby, P. G., 2001. Chronostratigraphic techniques in recent sediments. In Last, W. M. \& J. P. Smol (eds), Tracking Environmental Change Using Lake Sediments. Volume 1: Basin Analysis, Coring and Chronological Techniques. Kluwer, Dordrecht: 171-203.

Anderson, N.J, 1990. Variability of diatom concentrations and accumulation rates in sediments of a small lake basin. Limnology and Oceanography 35: 497-508.

Battarbee, R. W., J. A. Grytnes, R. Thompson, P. G. Appleby, J. Catalan, A. Korhola, H. J. B. Birks, E. Heegaard \& A. Lami, 2002. Comparing palaeolimnological and instrumental evidence of climate change for remote mountain lakes over the last 200 years. Journal of Paleolimnology 28: 161-179.

Battarbee, R. W., M. Kernan \& N. Rose, 2009. Threatened and stressed mountain lakes of Europe: assessment and progress. Aquatic Ecosystem Health \& Management 12: 118-128.

Blais, J. M., \& J. Kalff, 1995. The influence of lake morphometry on sediment focusing. Limnology and Oceanography, 40: 582-588.

Catalan, J., M. G. Barbieri, F. Bartumeus, P. Bitušík, I. Botev, A. Brancelj, D. Cogălniceanu, M. Manca, A. Marchetto, N. Ognjanova-Rumenova, S. Pla, M. Rieradevall, S. Sorvari, E. Štefkova, E. Stuchli \& M. Ventura, 2009. Ecological thresholds in European alpine lakes. Freshwater Biology 54: 2494-2517.

Catalan, J., M. Ventura1, A. Brancelj, I. Granados, H. Thies \& U. Nickus, 2002. Seasonal ecosystem variability in remote mountain lakes: implications for detecting climatic signals in sediment records. Journal of Paleolimnology 28: 25-46.

Catalan, J., S. Pla-Rabés, A. P. Wolfe, J. P. Smol, K. M. Rühland, N. J. Anderson, J. Kopáček, E. Stuchlík, R. Schmidt, K. A. Koinig, L. Camarero, R. J. Flower, O. Heiri, C. Kamenik, A. Korhola, P. R. Leavitt, R. Psenner, I. Renberg, 2013. Global change revealed by palaeolimnological records from remote lakes: a review. Journal of Paleolimnology 49: 513-535.

Chen, G., C. Dalton \& D. Taylor, 2010. Cladocera as indicators of trophic state in Irish lakes. Journal of Paleolimnology 44: 465-481.

Chiang, S. C. \& N. S. Du, 1979. Fauna Sinica, Crustacean: Freshwater Cladocera. Science Press, Academia Sinica, Beijing. (in Chinese).

Demott, W. R. \& W. C. Kerfoot, 1982. Competition Among Cladocerans Nature of the Interaction Between Bosmina and Daphnia. Ecology 63: 1949-1966.

Demott, W. R., 1982. Feeding selectivities and relative ingestion rates of Daphnia and Bosmina. Ecology 63: 1949-1966.

Dodson, S. I. \& D. G. Frey, 2001. Cladocera and other branchiopoda. In Thorp, H. J. \& A. P. Covich (eds) Ecology and classification of North American freshwater invertebrates. Academic Press, London: 723-786. 
Eggermont, H. \& K. Martens, 2011. Preface: Cladoceran crustaceans: sentinels of environmental change. Hydrobiologia 676: 1-7.

Elser, J. J., T. Andersen, J. S. Baron, A. K. Bergström, M. Jansson, M. Kyle, K. R. Nydick, L. Steger \& D. O. Hessen, 2009. Shifts in lake N: P stoichiometry and nutrient limitation driven by atmospheric nitrogen deposition. Science 326: 835-837.

Frey, D. G., 1986. Cladocera analysis. Cladocera analysis. In Berglund, B. E. (ed.), Handbook of Holocene Palaeoecology and Palaeohydrology. Wiley, Chichester: 667-692.

Frey, D. G., 1988. Littoral and offshore communities of diatoms, Cladocerans and dipterous larvae, and their interpretation in paleolimnology. Journal of Paleolimnology 1: 179-191.

Gąsiorowski, M. \& K. Szeroczyńska, 2004. Abrupt changes in Bosmina (Cladocera, Crustacea) assemblages during the history of the Ostrowite Lake (northern Poland). Hydrobiologia 526: 137-144.

George, D. G. \& D. P. Hewitt, 2006. The impact of year-to-year changes in the weather on the dynamics of Daphnia in a thermally stratified lake. Aquatic Ecology 40: 33-47.

Grimm, E. C., 2011. TILIA software version 1.7.16. Illinois State Museum, Research and Collection Center. Springfield USA. Available: http://intra.museum.state.il.us/pub/grimm/tilia/

Hofmann, W., 1987. Cladoceran in space and time: analysis of lake sediments. Hydrobiologia 145: 315-321.

Holtgrieve, G. W., D. E. Schindler, W. O. Hobbs, P. R. Leavitt, E. J. Ward, L. Bunting, G. Chen, B. P. Finney, I. Gregory-Eaves, S. Holmgren, M. J. Lisac, P. J. Lisi, K. Nydick, L. A. Rogers, J. E. Saros, D. T. Selbie, M. D. Shapley, P. B. Walsh \& A. P. Wolfe, 2011. A coherent signature of anthropogenic nitrogen deposition to remote watersheds of the Northern Hemisphere. Science 334: 1545-1548.

Hu, Z., N. J. Anderson, X. Yang \& S. McGowan, 2014. Catchment-mediated atmospheric nitrogen deposition drives ecological change in two alpine lakes in SE Tibet. Global Change Biology 20: 1614-1628.

Jeppesen E., J. P. Jensen, M. Søndergaard, T. Lauridsen, L. J. Pedersen \& L. Jensen, 1997. Top-down control in freshwater lakes the role of nutrient state, submerged macrophytes and water depth. Hydrobiology $119: 151-164$.

Jeppesen, E., J. P. Jensen, T. L. Lauridsen, S. L. Amsinck, K. Christoffersen, M. Søndergaard \& S. F. Mitchell, 2003. Sub-fossils of cladocerans in the surface sediment of 135 lakes as proxies for community structure of zooplankton, fish abundance and lake temperature. Hydrobiologia 491: 321-330.

Jeppesen, E., K. Christoffersen, F. Landkildehus, T. Lauridsen, S. L. Amsinck, F. Riget \& M. Søndergaard, 2001. Fish and crustaceans in northeast Greenland lakes with special emphasis on interactions between Arctic charr (Salvelinus alpinus), Lepidurus arcticus and benthic chydorids. Hydrobiologia 442: 329-337.

Kamenik, C., K. Szeroczyńska \& R. Schmidt, 2007. Relationships among recent Alpine Cladocera remains and their environment: implications for climate-change studies. Hydrobiologia 594: 33-46.

Kankaala, P., 1988. The relative importance of algae and bacteria as food for Daphnia longispina Cladocera in a polyhumic lake. Freshwater Biology 19: 285-296.

Kattel, G. R., R. W. Battarbee, A. Mackay \& H. J. B. Birks, 2007. Are cladoceran fossils in lake sediment samples a biased reflection of the communities from which they are derived?. Journal of Paleolimnology 38: 157-181.

Kattel, G. R., R. W. Battarbee, A. W. Mackay \& H. J. B. Birks, 2008. Recent ecological change in a remote Scottish mountain loch: an evaluation of a Cladocera-based temperature transfer-function. Palaeogeography Palaeoclimatology Palaeoecology 259: 51-76. 
Kattel, G. R.., 2009. Application of sediment traps in global change research in mountain lakes. Journal of Mountain Science 6: 228-239.

Koinig, K. A., C. Kamenik, R. Schmidt, A. Agustí-Panareda, P. Appleby, A. Lami, M. Prazakova, N. Rose, Ø. A. Schnell, R. Tessadri, R. Thompson \& R. Psenner, 2002. Environmental changes in an alpine lake (Gossenköllesee, Austria) over the last two centuries-the influence of air temperature on biological parameters. Journal of Paleolimnology 28: 147-160.

Korhola, A., 1999. Distribution patterns of Cladocera in subarctic Fennoscandian lakes and their potential in environmental reconstruction. Ecography 22: 357-373.

Korhola, A. \& M. Rautio, 2001. Cladocera and other branchiopod crustaceans. In: Tracking environmental change using lake sediments. Kluwer, Dordrecht: 5-41.

Kuang, X. Y., J. Liu, H. L. Wang \& S. M. Wang, 2008. Inter-hemispheric comparison of climate change in the last millennium based on the ECHO-G simulation. Chinese Science Bulletin 53: 2692-2700.

Larsen, C. P. S., \& G. M. MacDonald. 1993. Lake morphometry, sediment mixing and the selection of sites for fine resolution palaeoecological studies. Quaternary Science Reviews 12: 781-792.

Liang, E. Y., X. M. Shao \& Y. Xu, 2009. Tree-ring evidence of recent abnormal warming on the southeast Tibetan Plateau. Theoretical and Applied Climatology 98: 9-18.

Lotter, A. F., H. J. B. Birks, W. Hofmann \& A. Marchetto, 1997. Modern diatom, cladocera, chironomid, and chrysophyte cyst assemblages as quantitative indicators for the reconstruction of past environmental conditions in the Alps. I. Climate. Journal of Paleolimnology 18: 395-420.

Lotter, A. F., H. J. B. Birks, W. Hofmann \& A. Marchetto, 1998. Modern diatom, cladocera, chironomid, and chrysophyte cyst assemblages as quantitative indicators for the reconstruction of past environmental conditions in the Alps. II. Nutrients. Journal of Paleolimnology 19: 443-463.

Manca, M. \& P. Comoli, 1995. Temporal variations of fossil Cladocera in the sediments of Lake Orta (N. Italy) over the last 400 years. Journal of Paleolimnology 14: 113-122.

Manca, M. \& P. Comoli, 2004. Reconstructing long-term changes in Daphnia's body size from subfossil remains in sediments of a small lake in the Himalayas. Journal of Paleolimnology 32: 95-107.

Neff, J.C., A.P. Ballantyne, G.L. Farmer , N. M. Mahowald., J. L. Conroy., C. C. Landry., J. T. Overpeck., T. H. Painetr., C. R. Lawrence \& R. L. Reynolds, 2008. Increasing eolian dust deposition in the western United States linked to human activity. Nature Geoscience 1: 189-195.

Nevalainen, L., T. P. Luoto, S. Kultti \& K. Sarmaja-Korjonen, 2013. Spatio-temporal distribution of sedimentary Cladocera (Crustacea: Branchiopoda) in relation to climate. Journal of Biogeography 40: 1548-1559.

Persson, J., M.T. Brett, T. Vrede \& J. L. Ravet, 2007. Food quantity and quality regulation of trophic transfer between primary producers and a keystone grazer (Daphnia) in pelagic freshwater food webs. Oikos, 116: 1152-1163.

Rühland, K., N. Phadtare, R. Pant, S. Sangode \& J. Smol, 2006. Accelerated melting of Himalayan snow and ice triggers pronounced changes in a valley peatland from northern India. Geophysical research letters 33: L15709.

Saros, J. E., K. C. Rose, D. W. Clow, V. C. Stephens, A. B. Nurse, H. A. Arnett, J. Stone, C. E. Williamson \& A. P. Wolfe, 2010. Melting alpine glaciers enrich high-elevation lakes with reactive nitrogen. Environmental Science \& Technology 44: 4891-4896. 
Scholten, M. C. T., E. M. Foekema, H. P. Dokkum, N. H. B. M. Kaag \& R. G. Jak, 2005. Daphnid Grazing Ecology. In Eutrophication Management and Ecotoxicology. Environmental Science. Springer, Berlin: 21-56.

Shao, X. \& J. Fan, 1999. Past climate on west Sichuan Plateau as reconstructed from ring-widths of dragon spruce. Quaternary Sciences 1: 81-89. (in Chinese).

Smol, J. P., A. P. Wolfe, H. J. B. Birks, M. S. Douglas, V. J. Jones, A. Korhola, R. Pienitzj, K. Rühlanda, S. Sorvarii, D. Antoniadesh, S. J. Brooksk, M. A. Falluj, M. Hughesg, B. E. Keatleya, T. E. Laingj, N. Micheluttia, L. Nazaroval, M. Nymani, A. M. Patersona, B. Perrenh, R. Quinlanh, M. Rautioi, E. Saulnier-Talbot, S. Siitoneni, N. Solovievag \& J. Weckströmi, 2005. Climate-driven regime shifts in the biological communities of arctic lakes. Proceedings of the National Academy of Sciences of the United States of America 102: 4397-4402.

Szeroczyńska, K. \& K. Sarmaja-Korjonen, 2007. Atlas of Subfossil Cladoceran from Central and Northern Europe. Friends of the Lower Vistula Society, Świecie.

ter Braak, C. J. F., \& P. Šmilauer, 2002. CANOCO Reference Manual and CanoDraw for Windows User's Guide: Software for Canonical Community Ordination. Version 4.5. Microcomputer Power, Ithaca, NY.

Thienpont, J. R., J. B. Korosi1, E. S. Cheng, K. Deasley, M. F. J. Pisaric \& J. P. Smol, 2015. Recent climate warming favours more specialized cladoceran taxa in western Canadian Arctic lakes. Journal of Biogeography 42: 1553-1565.

Thompson, L. G., T. Yao, E. Mosley-Thompson, M. E. Davis, K. A. Henderson \& P. N. Lin, 2000. A high-resolution millennial record of the South Asian monsoon from Himalayan ice cores. Science 289: 1916-1919.

Wang, R., X. Yang, P. Langdon \& E. Zhang, 2011. Limnological responses to warming on the Xizang Plateau, Tibet, over the past 200 years. Journal of Paleolimnology 45: 257-271.

Weider, L. J., 1987. Life history variation among low-arctic clones of obligately parthenogenetic Daphnia pulex: a diploid-polyploid complex. Oecologia 73: 251-256.

Whiteside, M. C., J. B. Williams \& C. P. White, 1978. Seasonal abundance and pattern of chydorid, Caldocera in mud and vegetative habitats. Ecology 59: 1177-1188.

Wischnewski, J., A. Kramer, Z. Kong, A. Mackay, G. Simpson, S. Mischke \& U. Herzschuh, 2011. Terrestrial and aquatic responses to climate change and human impact on the southeastern Tibetan Plateau during the past two centuries. Global Change Biology 17: 3376-3391.

Wolfe A.P., J.S. Baron \& R.J. Cornett, 2001. Anthropogenic nitrogen deposition induces rapid ecological changes in alpine lakes of the Colorado Front Range (USA). Journal of Paleolimnology 25: 1-7. 


\section{Figures}
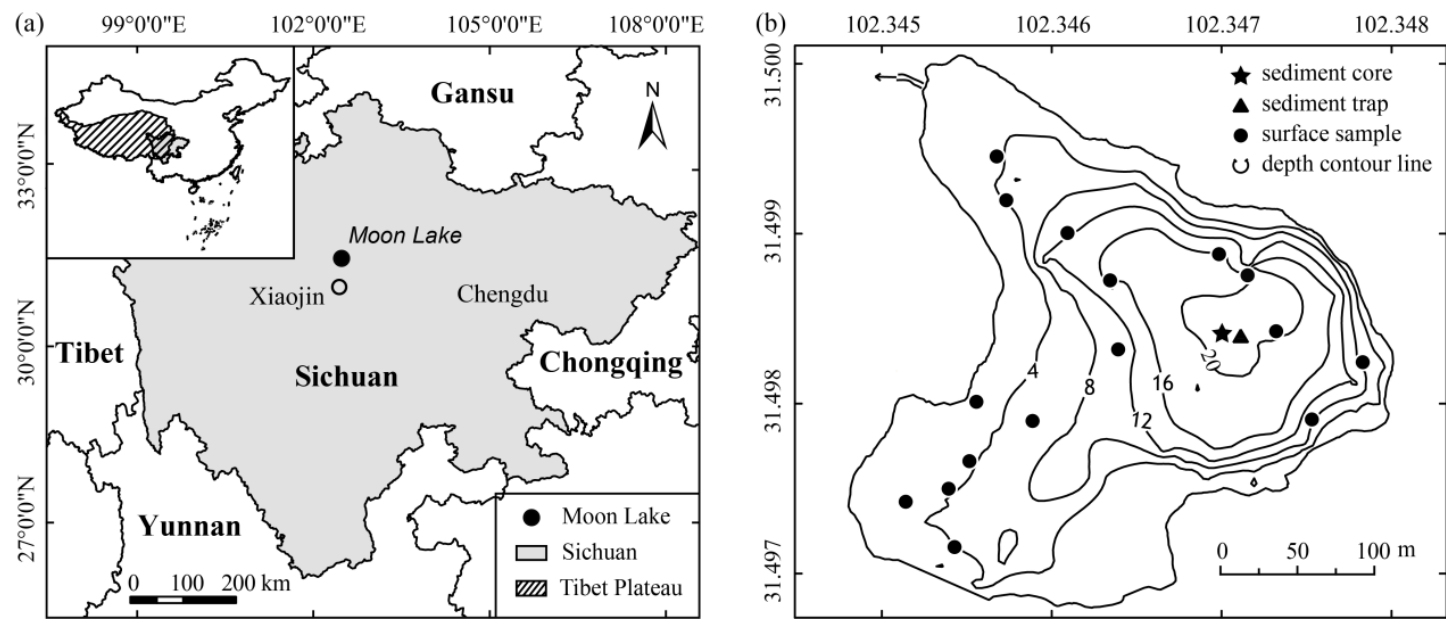

Fig. 1 The location and lake morphometry of Moon Lake and sediment sampling sites in the lake. (a) The location of the Moon Lake in the Tibetan border of the Sichuan Province in SW China; (b) lake morphometry (revised from Hu et al. (2014) with sediment sampling sites, also shown are the sediment traps which were deployed at $5 \mathrm{~m}$ and $15 \mathrm{~m}$ below the surface of the water. Surface sediment sampling points are shown as solid circles, the star represents the location of sediment core, and the sediment trap location is shown as a triangle 

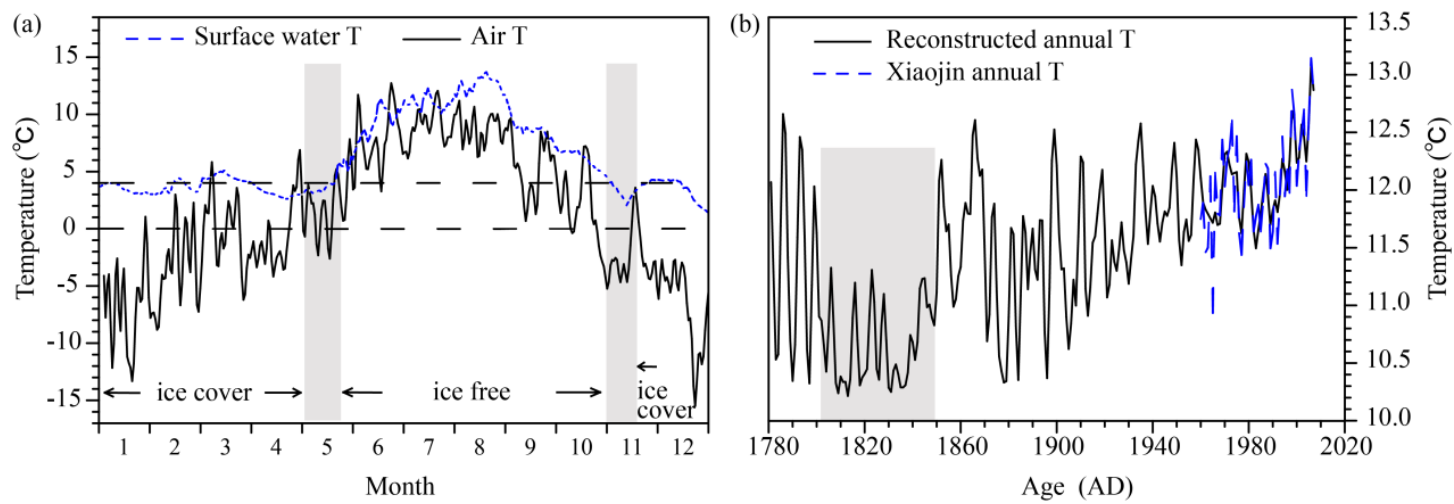

Fig. 2 Climate data for the study site as well as the reconstructed mean annual air temperature records for region. (a) Surface water temperature for 2013 and mean seven-day average air temperatures; the shaded columns indicate when water column was isothermal (May and November); (b) reconstructed mean annual air temperatures for the Xiaojin County derived by using the ECHO-G model based on instrumental data from the meteorological station in Xiaojin County, where the shaded part is the cold period referred to as the Little Ice Age (LIA) in the main text 
(a)
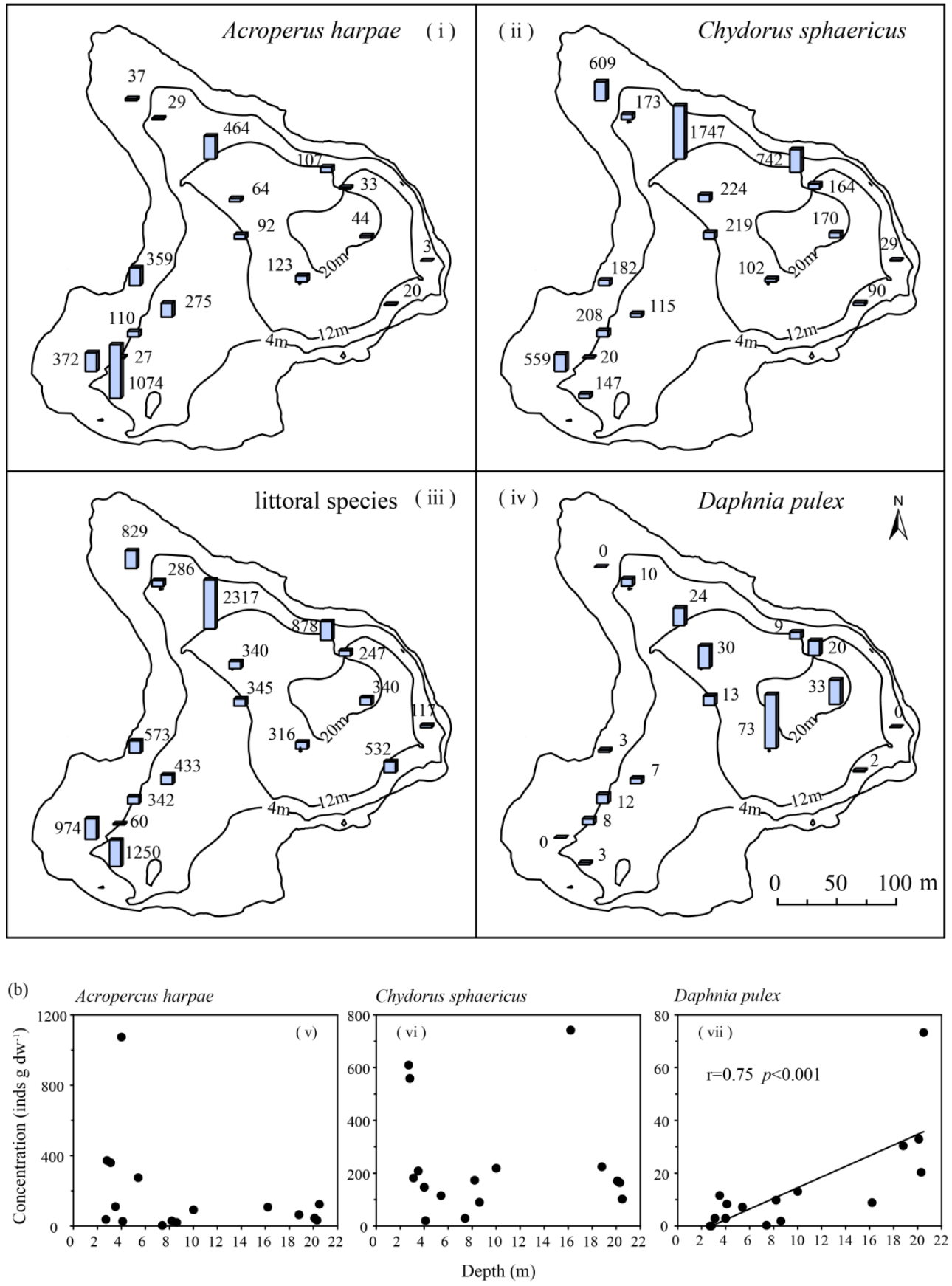

Fig. 3 The spatial distribution of of selected cladoceran taxa and total littoral species (as concentrations, individuals per gram of dry weight sediment [inds $\mathrm{g} \mathrm{dw}^{-1}$ ]) together with their relationship to water depth (inserts). The sampling sites for surface-sediment samples across the basin are shown (black dots). Correlation between D. pulex and selected concentration and water depth is significant. The contour maps were created using the Surfer 9.0 (Golden Software). 

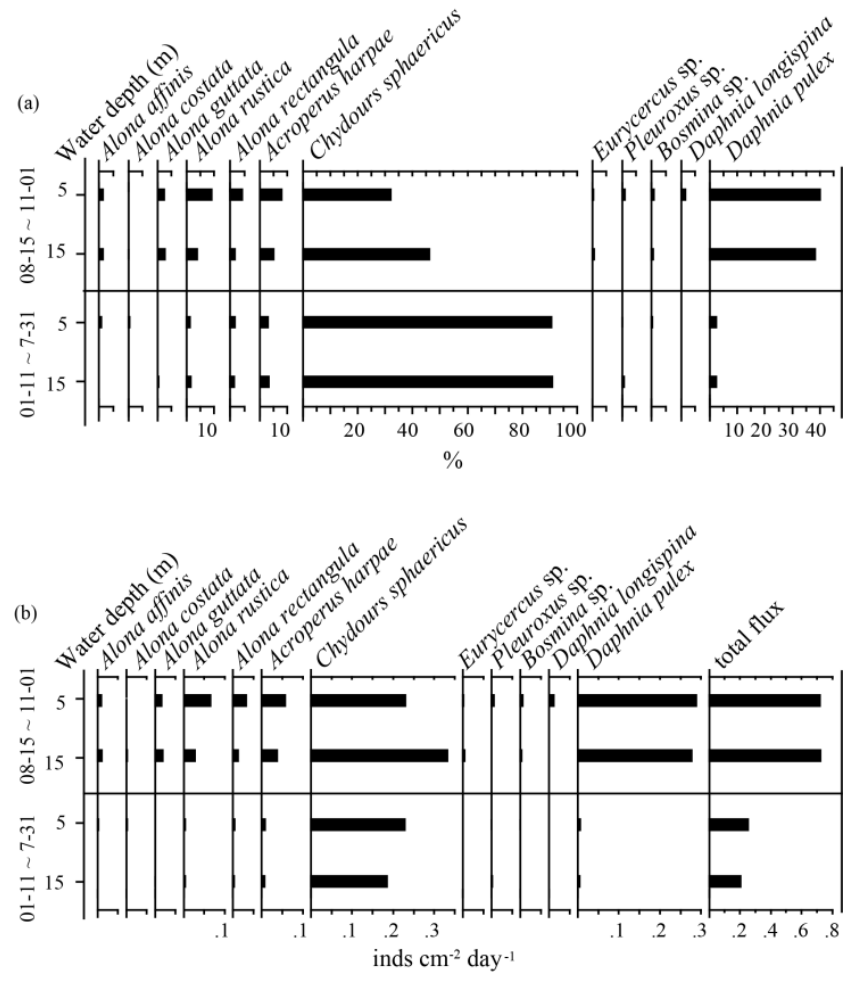

Fig. 4 Relative abundances (\%) and catch (ind. $\mathrm{cm}^{-2} \mathrm{~d}^{-1}$ ) of cladoceran remains in the traps from both early and late growing seasons at $5 \mathrm{~m}$ and $15 \mathrm{~m}$ below the water surface. The period from the 15 August 2013 to 1 November 2013 represents the late ice-free period or late growing season, and the period from 1 November 2013 to the end of July 2014 represents approximately the early growing season. 


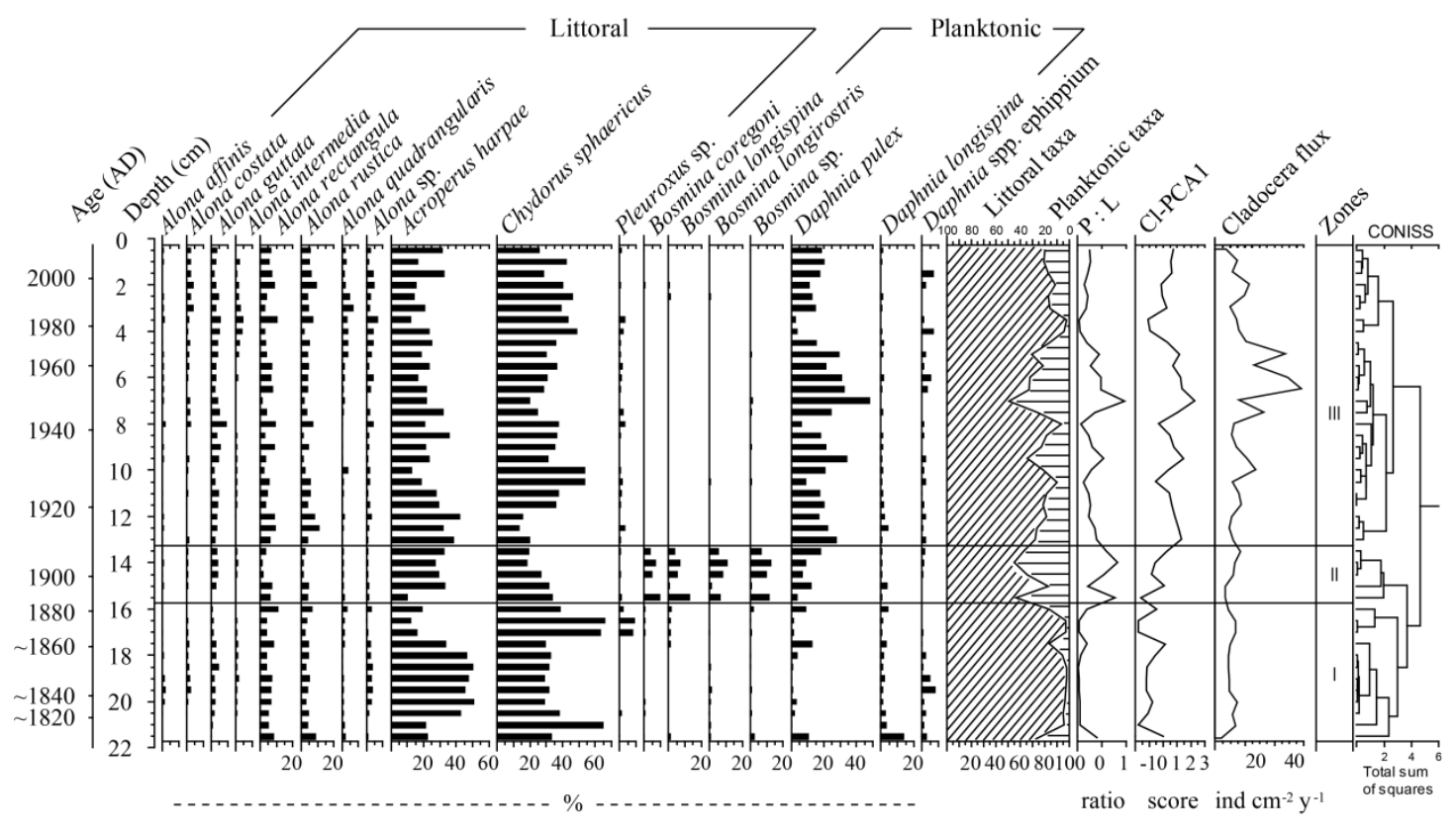

Fig. 5 Relative abundances and accumulation rates of the common cladoceran species found in the sediment core. Zonation was based on the constrained incremental sum of squares (CONISS) within the computer programs Tilia Graph 


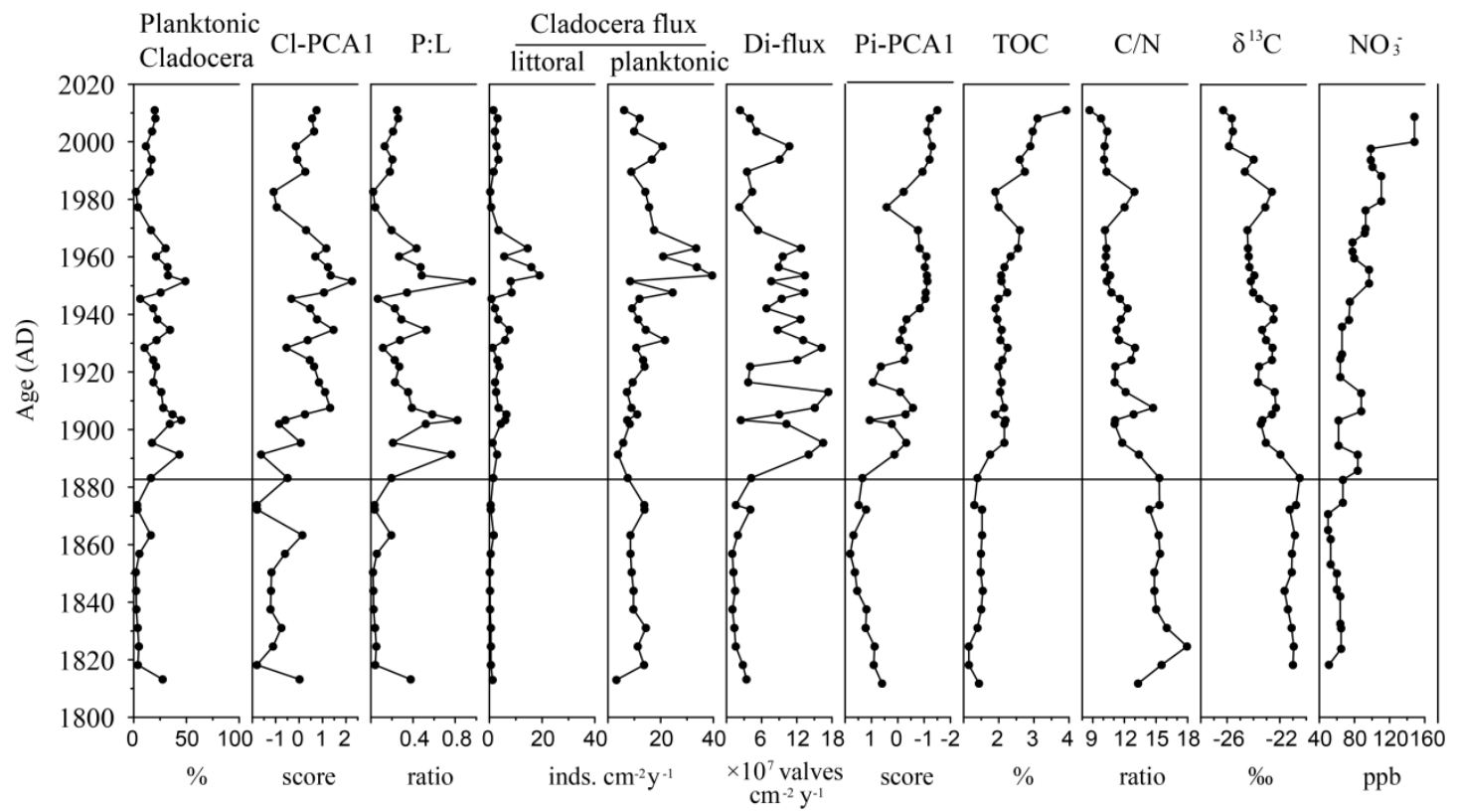

Fig. 6 Summary of the multi-proxy palaeolimnological data (cladocera, diatoms, pigments, geochemistry) from the Moon Lake sediment core together and independent environmental drivers $\left(\mathrm{NO}_{3}\right.$ and temperature). The Cl-PCA1 represents the cladoceran PCA1 Axis 1 sample score calculated from percentage data, Di-PCA-2 and Pi-PCA1 represents the main changes in the diatom assemblages and pigments respectively (see $\mathrm{Hu}$ et al. 2014). $\mathrm{NO}_{3}{ }^{-}$concentration data was taken from the Himalayan ice core (Thompson et al., 2000). The mean annual temperature was reconstructed using the ECHO-G model based on the instrumental data starting from 1960 in Xiaojin County 